\title{
Paideusis
}

\section{Claiming an Education: Feminism and Canadian Schools (Jane Gaskell, Arlene McLaren, and Myra Novogrodsky)}

\section{Elizabeth Reilly}

Volume 8, Number 2, 1995

URI: https://id.erudit.org/iderudit/1073257ar

DOI: https://doi.org/10.7202/1073257ar

See table of contents

Publisher(s)

Canadian Philosophy of Education Society

ISSN

0838-4517 (print)

1916-0348 (digital)

Explore this journal

Cite this review

Reilly, E. (1995). Review of [Claiming an Education: Feminism and Canadian Schools (Jane Gaskell, Arlene McLaren, and Myra Novogrodsky)]. Paideusis, 8(2), 43-44. https://doi.org/10.7202/1073257ar viewed online.

https://apropos.erudit.org/en/users/policy-on-use/ 


\section{Book Reviews}

Jane Gaskell, Arlene McLaren, and Myra Novogrodsky. Claiming an Education: Feminism and Canadian Schools. Toronto, ON: Our Schools/ Our Selves Education Foundation and Garamond Press, 1989.

This book is a comprehensive introduction to Canadian educational issues in relation to their impact on feminist theory and the socialist feminist political agenda in Canada. It is a short book-exactly 100 pages-and is divided into four easily absorbed chapters which discuss, respectively, equality of opportunity; defining the feminist curriculum; teachers, child care workers and mothers; and post-secondary education. The three authors represent different perspectives on educational issues, as well as different geographic regions. Gaskell and McLaren are both university researchers and instructors in British Columbia, while Novogrodsky teaches at City School in Toronto and coordinates Women's and Labour Studies for the Toronto Board of Education. The authors note in their introduction the difficulty of finding a balance between discussion of classroom practices and research literature-that is, between a practical voice and an academic one.

The final version of the book seems to have managed the compromise they sought in earlier drafts. The authors describe and offer examples of particular policies which have attempted to address issues such as employment equity and gender stereotyping in the Canadian curriculum. In particular, it is good to see employment equity described in relation to the Canadian context. Statistics are also offered indicating the relative success of some of these programmes. The authors review the research literature which surrounds the issues from both theoretical and empirical studies. They discuss the "deficit model" and the harm done to women who are assumed to bring deficits to their experiences of education. They argue that it is not enough to expect individual girls and women to overcome their "fear of success" or other stereotyped assumptions about career goals; the institutions within which these girls will work must also be transformed in ways that will make them more "woman friendly." The authors go on to present and dispel a number of myths about unequal power and the ways in which a woman's failure to "achieve" in specific instances is blamed on the individual herself rather than the system within which she works.

While the variety of modes of analysis provides both an interesting and a useful overview, two aspects are underdeveloped. At the most practical level, the book might have offered more immediate suggestions for practical classroom strategies. For example, the authors argue:

Feminists must ask what kind of curriculum can be important and relevant for women; what kind of a curriculum can integrate theory with the practices of women's lives, allowing students to assess critically the grounds of their exploitation and to work for change. (p. 40)

They do not, however, tell us what this curriculum might look like, except for listing on the next page some ways in which women's experiences and contributions may be added to existing courses of study. 
At the theoretical level, there is little discussion of the concept of gender, of liberalism versus socialism, or of the implications of the socialist feminist perspective the authors have taken. For example, in a discussion of employment equity, they argue that "the strategy of equal value has more transformative potential than the fight to get women into 'men's' jobs or to achieve equal pay for the same jobs" (p. 76). They do not tell us what is meant by transformative potential, nor do they explain why this is important. In their introduction, the authors suggest that a socialist-feminist theoretical framework will underpin their discussion of the various issues. They promise that in their final chapter they will draw conclusions regarding the relationship between a socialist feminist politics and some of the issues raised in the book. But the only arguments offered in support of their theoretical position are contained in a few short sentences on the second-to-last-page. The authors do not have a duty to defend socialist feminism, for this work has been done by others in texts more specifically theoretical in nature. But for those new to feminist study, this omission may pose problems.

The authors do not make it clear whom they hope will read the book. If the audience is to be pre-service teachers, the book will likely useful in raising awareness of certain vital issues, but it does not go far enough in terms of specific strategies a teacher might utilize. On the other hand, as I have argued, the theoretical underpinnings of the feminist perspective they assume are not defended either. This book supposes that the reader already sides with the authors. It does not persuade; rather, it makes strong statements which will be problematic for pre-feminists.

However, the book can be wholeheartedly recommended to students of feminism who are new to the field of education. As an overview of educational issues within a broader feminist perspective, this book is informative and provides a sensible starting place for further studies in feminist pedagogy and in girls' and women's education and careers. Its lack of practical in-class suggestions will not be a problem, nor will its assumptions regarding the theoretical background of the reader. The authors are to be commended for their clear language and straightforward style

Reviewed by Elizabeth Reilly, University of British Columbia 